\title{
Characterization of $\beta$-glucosidase from Aspergillus terreus and its application in the hydrolysis of soybean isoflavones ${ }^{*}$
}

\author{
Feng-ying YAN, Wei XIA, Xiao-xu ZHANG, Sha CHEN, Xin-zheng NIE, Li-chun QIAN ${ }^{\dagger *}$ \\ (The Key Laboratory of Molecular Animal Nutrition, Ministry of Education, College of Animal Sciences, Zhejiang University, Hangzhou 310058, China) \\ ${ }^{\dagger}$ E-mail: lcqian@zju.edu.cn \\ Received Dec. 15, 2015; Revision accepted May 5, 2016; Crosschecked May 12, 2016
}

\begin{abstract}
An extracellular $\beta$-glucosidase produced by Aspergillus terreus was identified, purified, characterized and was tested for the hydrolysis of soybean isoflavone. Matrix-assisted laser desorption/ionization with tandem time-offlight/time-of-flight mass spectrometry (MALDI-TOF/TOF MS) revealed the protein to be a member of the glycosyl hydrolase family 3 with an apparent molecular mass of about $120 \mathrm{kDa}$. The purified $\beta$-glucosidase showed optimal activity at $\mathrm{pH} 5.0$ and $65^{\circ} \mathrm{C}$ and was very stable at $50{ }^{\circ} \mathrm{C}$. Moreover, the enzyme exhibited good stability over $\mathrm{pH}$ 3.0-8.0 and possessed high tolerance towards pepsin and trypsin. The kinetic parameters $K_{\mathrm{m}}$ (apparent MichaelisMenten constant) and $V_{\max }$ (maximal reaction velocity) for $p$-nitrophenyl- $\beta$-D-glucopyranoside $(p N P G)$ were $1.73 \mathrm{mmol} / \mathrm{L}$ and $42.37 \mathrm{U} / \mathrm{mg}$, respectively. The $K_{\mathrm{m}}$ and $V_{\max }$ for cellobiose were $4.11 \mathrm{mmol} / \mathrm{L}$ and $5.7 \mathrm{U} / \mathrm{mg}$, respectively. The enzyme efficiently converted isoflavone glycosides to aglycones, with a hydrolysis rate of $95.8 \%$ for daidzin, $86.7 \%$ for genistin, and $72.1 \%$ for glycitin. Meanwhile, the productivities were $1.14 \mathrm{mmol} /(\mathrm{L} \cdot \mathrm{h})$ for daidzein, $0.72 \mathrm{mmol} /(\mathrm{L} \cdot \mathrm{h})$ for genistein, and $0.19 \mathrm{mmol} /(\mathrm{L} \cdot \mathrm{h})$ for glycitein. This is the first report on the application of $A$. terreus $\beta$-glucosidase for converting isoflavone glycosides to their aglycones in soybean products.
\end{abstract}

Key words: $\beta$-glucosidase, Aspergillus terreus, Characterization, Hydrolysis, Soybean isoflavones http://dx.doi.org/10.1631/jzus.B1500317

CLC number: Q55

\section{Introduction}

Isoflavones, a class of nonsteroidal estrogens, are diphenolic secondary metabolites of plants and are frequently abounded in soybeans (Glycine max). They have attracted considerable attention for their pharmacological effects, such as preventing certain cancers (breast, prostate, and colon) (Ravindranath et al., 2004; Ullah et al., 2016), decreasing the risk of cardiovascular diseases (Imai, 2015), improving bone

\footnotetext{
* Corresponding author

* Project supported by the Innovation Team Program of Zhejiang Province (No. 2011R50025-12), China

\# Electronic supplementary materials: The online version of this article (http://dx.doi.org/10.1631/jzus.B1500317) contains supplementary materials, which are available to authorized users

(1) ORCID: Feng-ying YAN, http://orcid.org/0000-0002-6884-7094; Li-chun QIAN, http://orcid.org/0000-0001-8699-1885

(C) Zhejiang University and Springer-Verlag Berlin Heidelberg 2016
}

health (Alekel et al., 2015), and preventing menopausal symptoms (Ko, 2013). Moreover, studies revealed that isoflavone aglycones, such as daidzein and genistein, are superior to isoflavone glycosides in various bioactivities. However, most of the isoflavones in natural food exist as isoflavone glycosides and are difficult to absorb in the intestines (Izumi et al., 2000). Thus, to obtain good bioavailability and pharmacological effects, isoflavone glycosides need to be hydrolyzed to aglycones.

$\beta$-Glucosidases ( $\beta$-D-glucoside glucohydrolase, EC 3.2.1.21) mainly hydrolyze the $\beta-1,4$-glucosidic linkage in various disaccharides, oligosaccharides,

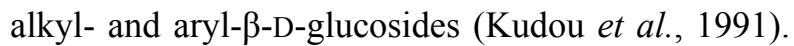
They have attracted considerable interest due to their important roles in a variety of fundamental biological processes, such as the hydrolysis in glucosides of isoflavones (Matsuura and Obata, 1993), bio-ethanol 
production (Coughlan, 1985), pharmaceutical (Zhou et al., 2012) and flavor production (Gueguen et al., 1996). According to the amino acid sequences, $\beta$-glucosidases have been classified into glycoside hydrolase (GH) families $\mathrm{GH} 1, \mathrm{GH} 3, \mathrm{GH} 5, \mathrm{GH}$, GH30, and GH116 (http://www.cazy.org). The majority of fungal $\beta$-glucosidases belong to $\mathrm{GH} 1$ and GH3. The nutritional availability of foods and feeds can be improved for the release of vitamins, antioxidants, aglycones, and other beneficial compounds from their glycosides by adding $\beta$-glucosidases. Therefore, animal feeds are often treated with crude $\beta$-glucosidases (Cairns and Esen, 2010). Desired features which are important to the animal feed applications of $\beta$-glucosidases include high hydrolysis activity, good thermostability and $\mathrm{pH}$ stability, and high pepsin and trypsin tolerance.

The possibilities for different industrial applications of $\beta$-glucosidases justify the incessant search for new sources of microbial enzymes that can be produced with high structural stability in low economic value fermentation media (de Cassia Pereira et al., 2015). Fungal strains are known to be efficient producers of $\beta$-glucosidases (Souza et al., 2010). There have been several reports (Workman and Day, 1982; Rodionova et al., 1987; Nazir et al., 2008; Elshafei et al., 2014) about the purification of $\beta$-glucosidase from Aspergillus terreus; however, there have not been any investigations about their potential industrial applications. In this study, the newly isolated strain of fungus, A. terreus, can produce extracellular $\beta$-glucosidases with outstanding pepsin and trypsin tolerance, which indicates the potential applications in animal feeds. The absence of reports in scientific literature of this fact encouraged us to study the physicochemical characteristics and the industrial applicabilities of the $A$. terreus $\beta$-glucosidases (At-Bgls).

\section{Materials and methods}

\subsection{Materials}

$p$-Nitrophenyl- $\beta$-D-glucopyranoside ( $p \mathrm{NPG}$ ) and cellobiose were purchased from the Sigma-Aldrich Corp. (St. Louis, MO, USA). Pepsin (2500 U/mg) and trypsin $(2500 \mathrm{U} / \mathrm{mg})$ were purchased from the Shanghai Songon Company (Shanghai, China). Soybeans (Zhongdou-27) were provided by the Center of Soybean Research, Zhejiang Agricultural Academy
(Hangzhou, China). Isoflavone glycosidic standards (daidzin, genistin, and glycitin) and isoflavone aglycone standards (daidzein, genistein, and glycitein) were purchased from the Sigma Chemical Co. (St. Louis, MO, USA). All other chemicals used were analytical-grade reagents unless otherwise stated.

\subsection{Organism and culture condition}

A. terreus (Trichocomaceae, Eurotiales, Ascomycota) was isolated from composting soil of the Jinhua region, located in Zhejiang Province, China, and was identified by its $18 \mathrm{~S}$ DNA sequence. The strain was maintained in potato dextrose agar (PDA; $200 \mathrm{~g}$ potato, $20 \mathrm{~g}$ glucose, $20 \mathrm{~g}$ agar, $1000 \mathrm{ml}$ distilled water) slant at $4{ }^{\circ} \mathrm{C}$.

For the preparation of inoculum, an agar plug of $5 \mathrm{~mm}$ diameter cut out from the PDA containing mycelium was incubated into a $20-\mathrm{ml}$ basal medium, which had been autoclaved at $121{ }^{\circ} \mathrm{C}$ for $20 \mathrm{~min}$, containing $2 \mathrm{~g} / \mathrm{L}\left(\mathrm{NH}_{4}\right)_{2} \mathrm{SO}_{4}, 1 \mathrm{~g} / \mathrm{L} \mathrm{KH}_{2} \mathrm{PO}_{4}, 0.4 \mathrm{~g} / \mathrm{L}$ $\mathrm{MgSO}_{4} \cdot 7 \mathrm{H}_{2} \mathrm{O}$, and $0.5 \mathrm{~g} / \mathrm{L} \mathrm{CaCl}_{2}$. The culture was then incubated on a rotary shaker at $35^{\circ} \mathrm{C}$ for $24 \mathrm{~h}$.

After incubation, the mycelium was stained with methylene blue, rinsed, and examined under a microscope to prove its purity, and was then broken into pieces using a homogenizer. An aliquot $(1 \mathrm{ml})$ of the homogenate was incubated into $100 \mathrm{ml}$ culture media, which had been autoclaved at $121^{\circ} \mathrm{C}$ for $20 \mathrm{~min}$, containing $30 \mathrm{~g} / \mathrm{L}$ wheat bran, $4 \mathrm{~g} / \mathrm{L}\left(\mathrm{NH}_{4}\right)_{2} \mathrm{SO}_{4}, 1 \mathrm{~g} / \mathrm{L}$ $\mathrm{KH}_{2} \mathrm{PO}_{4}, 0.4 \mathrm{~g} / \mathrm{L} \mathrm{MgSO}{ }_{4} \cdot 7 \mathrm{H}_{2} \mathrm{O}$, and $0.5 \mathrm{~g} / \mathrm{L} \mathrm{CaCl}_{2}$. Submerged fermentation was carried out in $250-\mathrm{ml}$ flasks under continuous shaking $(180 \mathrm{r} / \mathrm{min})$ at $35^{\circ} \mathrm{C}$ for $5 \mathrm{~d}$ with the flask sealed with sterile gauze and a cap of kraft paper in order to avoid excessive water evaporation and microorganism contamination. The culture suspension was squeezed through sterile absorbent gauze and centrifuged at $8000 \mathrm{r} / \mathrm{min}$ for $30 \mathrm{~min}$ at $4{ }^{\circ} \mathrm{C}$. Thus, the cell-free culture supernatant was used for enzyme activity measurements and for the purification of $\beta$-glucosidase.

\subsection{Enzyme purification and molecular mass determination}

The cell-free culture supernatant was concentrated at $4{ }^{\circ} \mathrm{C}$ using Amicon Ultra-15 30K filter devices (Millipore, USA) and then dialyzed against a $20 \mathrm{mmol} / \mathrm{L}$ Tris- $\mathrm{HCl}$ buffer ( $\mathrm{pH}$ 7.5). The dialyzed enzyme solution was loaded onto a HiTrap Q HP column $(1.6 \mathrm{~cm} \times 2.5 \mathrm{~cm}$, Amersham Pharmacia, 
Uppsala, Sweden) which was pre-equilibrated with a $20 \mathrm{mmol} / \mathrm{L}$ Tris-HCl buffer ( $\mathrm{pH}$ 7.5). The column was first eluted with an equilibration buffer (two bed volumes) followed by a linear gradient of $1 \mathrm{~mol} / \mathrm{L}$ $\mathrm{NaCl}$ at $2.0 \mathrm{ml} / \mathrm{min}$. Then the fractions with high specific activity were pooled and concentrated using an Amicon Ultra-0.5 centrifugal Filter Unit with Ultracel-3 membrane (Millipore, USA).

The apparent molecular mass of the denatured protein was estimated by sodium dodecyl sulfatepolyarylamide gel electrophoresis (SDS-PAGE) (Laemmli, 1970) with 5\% (w/v) stacking polyacrylamide gel and $10 \%(\mathrm{w} / \mathrm{v})$ separating gel which run at $120 \mathrm{~V}$. The protein content in the fractions was determined using Lowry's method.

\subsection{Enzyme activity assay}

The $\beta$-glucosidase activity was determined using $p$ NPG as substrate. The reaction mixture contained $100 \mu \mathrm{l}$ of appropriately diluted enzyme, $100 \mu \mathrm{l}$ of $p$ NPG $(10 \mathrm{mmol} / \mathrm{L})$, and $300 \mu \mathrm{l}$ of McIlvaine buffer (100 mmol/L, pH 5.0). After incubation at $50{ }^{\circ} \mathrm{C}$ for $10 \mathrm{~min}$, the reaction was stopped by adding $500 \mu \mathrm{l}$ of $0.5 \mathrm{~mol} / \mathrm{L} \mathrm{Na}_{2} \mathrm{CO}_{3}$ and the absorbance was read at $405 \mathrm{~nm}$ for the amount of $p$-nitrophenol released. One unit of $\beta$-glucosidase activity was defined as the amount of enzyme that produced $1 \mu \mathrm{mol}$ of $p$ nitrophenol per minute under the conditions of the assay. The experiments were performed in triplicate.

\subsection{Effects of $\mathrm{pH}$ and temperature}

The optimum $\mathrm{pH}$ of the purified $\beta$-glucosidase was determined at $50{ }^{\circ} \mathrm{C}$ for $10 \mathrm{~min}$ in the range from $\mathrm{pH} 3.0$ to 8.0 using a $100 \mathrm{mmol} / \mathrm{L} \mathrm{McIlvaine}$ buffer containing $10 \mathrm{mmol} / \mathrm{L} p \mathrm{NPG}$. For the $\mathrm{pH}$ stability study, the enzyme was pre-incubated in the above buffer systems for $60 \mathrm{~min}$ at $25^{\circ} \mathrm{C}$. The residual activities at different $\mathrm{pH}$ levels were determined under standard assay conditions after the incubation.

The optimal temperature of the enzyme was measured at the temperature range from 35 to $85^{\circ} \mathrm{C}$ for $10 \mathrm{~min}$ in a McIlvaine buffer ( $100 \mathrm{mmol} / \mathrm{L}, \mathrm{pH}$ 5.0) containing $10 \mathrm{mmol} / \mathrm{L} p \mathrm{NPG}$. For the thermal stability study, the purified enzyme was pre-incubated at different temperatures $\left(50,60\right.$, and $\left.70{ }^{\circ} \mathrm{C}\right)$ in the absence of substrate. After incubation for different intervals (5-60 $\mathrm{min}$ ), the residual activity was evaluated. All experiments were performed in triplicate.

\subsection{Kinetic parameters}

The apparent Michaelis-Menten constant $\left(K_{\mathrm{m}}\right)$ and the maximal reaction velocity $\left(V_{\max }\right)$ for the purified $\beta$-glucosidase were assessed from LineweaverBurk plots using $p$ NPG or cellobiose as substrates. The enzyme was incubated in McIlvaine buffer (100 mmol/L, pH 5.0) with the substrate in concentrations ranging from 1.25 to $18.00 \mathrm{mmol} / \mathrm{L}$ of $p \mathrm{NPG}$ or $1.25-20.00 \mathrm{mmol} / \mathrm{L}$ of cellobiose at $65^{\circ} \mathrm{C}$ for $10 \mathrm{~min}$.

\subsection{Tolerance to pepsin and trypsin}

Glycine-HCl buffer (100 mmol/L, pH 3.0) containing $0.1 \%(1 \mathrm{~g} / \mathrm{L})$ pepsin and Tris- $\mathrm{HCl}$ buffer (100 mmol/L, pH 7.0) containing $0.1 \%(1 \mathrm{~g} / \mathrm{L})$ trypsin were prepared. To evaluate the tolerance to pepsin, the purified $\beta$-glucosidase $(1 \mathrm{mg} / \mathrm{ml})$ was incubated in glycine-HCl buffer solution for different intervals (30, $60,120 \mathrm{~min}$ ) with a $\beta$-glucosidase/pepsin mass ratio of $1: 1$ and 1:0.2, respectively. Similarly, the purified enzyme $(1 \mathrm{mg} / \mathrm{ml})$ was incubated in Tris- $\mathrm{HCl}$ buffer solution with a $\beta$-glucosidase/trypsin mass ratio of 1:0.1 and 1:0.02, respectively. After incubation, the residual activities were measured under standard assay conditions.

\subsection{Protein identification by a matrix-assisted laser desorption ionization tandem time using a flight mass spectrometry}

The band of glucosidase was manually excised from SDS-PAGE stained with Coomassie Brilliant Blue (CBB), and digested in gel overnight with trypsin as described by Oda et al. (2006). The gel piece was washed with Millipore pure water three times, destained twice with $50 \%$ acetonitrile in $25 \mathrm{mmol} / \mathrm{L}$ ammonium bicarbonate (Ambic) until the CBB disappeared, then reduced with $10 \mathrm{mmol} / \mathrm{L}$ dithiothreitol (DTT) in $25 \mathrm{mmol} / \mathrm{L}$ Ambic, alkylated with $55 \mathrm{mmol} / \mathrm{L}$ iodoacetamide in $25 \mathrm{mmol} / \mathrm{L}$ Ambic, dried twice with $100 \%$ acetonitrile, and digested overnight at $37{ }^{\circ} \mathrm{C}$ with sequencing grade modified trypsin (Promega, Madison, WI, USA) in $25 \mathrm{mmol} / \mathrm{L}$ Ambic. The peptides were extracted twice with $0.1 \%$ trifluoroacetic acid in 50\% acetonitrile. Samples were then spotted onto a freshly cleaned target plate and after air-drying, the crystallized spots were analyzed. Matrix-assisted laser desorption/ionization with tandem time-of-flight/ time-of-flight mass spectrometry (MALDI-TOF/TOF MS) analysis was performed using an ABI Sciex 5800 
MALDI-TOF/TOF MS Analyzer (AB SCIEX, Framingham, MA, USA). Thereafter, a database search was conducted using the MASCOT program online (http://www.matrixscience.com) against National Center for Biotechnology Information nonredundant (NCBInr) databases. The searching parameters were set as follows: tryptic digestion, one missed cleavage allowed, carbamidomethylation of cysteines as fixed modification, methionine oxidation as variable modification, all peptides monoisotopic, peptide mass tolerance of $100 \mathrm{ppm}\left(10^{-6}\right)$, and fragment mass tolerance of $0.3 \mathrm{Da}$. Only significant hits, as defined by the MASCOT probability analysis $(P<0.05)$, were accepted.

\subsection{Isoflavone extraction from soybean flour and enzymatic hydrolysis}

Soybeans were ground to powder using a coffee grinder and then defatted using petroleum ether, with a Soxhlet extractor. The defatted soybean flour $(1 \mathrm{~g})$ was extracted with $5 \mathrm{ml} 80 \%$ ethanol at $70{ }^{\circ} \mathrm{C}$ for $2 \mathrm{~h}$. The slurry was then centrifuged at $12000 \mathrm{r} / \mathrm{min}$ for $15 \mathrm{~min}$, and the supernatant was filtered through a $0.45-\mu \mathrm{m}$ filter and stored at $4{ }^{\circ} \mathrm{C}$ for further study.

To evaluate the potential application of At-Bgl in our study, the commonly used commercial $\beta$ glucosidase Novozyme 188 was used to hydrolyze the isoflavone glycosides. A $250-\mu 1$ reaction mixture containing $50 \mu \mathrm{l}$ soybean isoflavone extract was hydrolyzed with $0.025,0.050$, and $0.075 \mathrm{U}$ of individual $\beta$-glucosidase, respectively, in Mcllvaine buffer $(\mathrm{pH}$ 5.0) in a thermostatically controlled incubator at $50{ }^{\circ} \mathrm{C}$ for $10 \mathrm{~min}$. The reaction was stopped by boiling for $5 \mathrm{~min}$. A control reaction of extract samples without enzyme was set up in the same manner. The determination of isoflavone in hydrolyzed samples was determined by high performance liquid chromatography (HPLC) as previously described (Li et al., 2012). HPLC analyses were performed using a Waters HP1100 HPLC system (Milford, MA, USA) equipped with a Diamonsil C18 column $(5 \mu \mathrm{m}$,
$250 \mathrm{~mm} \times 4.6 \mathrm{~mm}$; Dima Co., Ltd., Orlando, FL, USA), and six types of high purity soybean isoflavones, daidzin, glycitin, genistin, daidzein, glycitein, and genistein, were used as standards. The productivity $(\mathrm{mmol} /(\mathrm{L} \cdot \mathrm{h}))$ of isoflavone aglycones was defined as the increase in the concentration produced in $1 \mathrm{~h}$ (Yeom et al., 2012). The hydrolysis effect was calculated by the following equation (Song et al., 2011): hydrolysis rate $=100 \% \times($ isoflavone glycosides in control samples-isoflavone glycosides in hydrolyzed samples)/isoflavone glycosides in the control samples.

\subsection{Statistical analysis}

Statistical analysis was performed using the one-way analysis of variance (ANOVA) procedure of the SPSS 19.0 statistical software package (IBM, Armonk, New York, USA). Treatment means were compared using Duncan's multiple range tests. It was declared significant when $P<0.05$.

\section{Results and discussion}

\subsection{Purification of $A$. terreus $\beta$-glucosidase}

The A. terreus culture mycelium was proved purity (Fig. S1) and the procedures to purify $\beta$ glucosidase from the crude extract of $A$. terreus are presented in Table 1. $\beta$-Glucosidase was purified from the culture supernatant of $A$. terreus by ultrafiltration and anion exchange, and the enzyme was 11.45 -fold purified to a specific activity of $25.73 \mathrm{U} / \mathrm{mg}$ with a yield of $7.62 \%$. The results suggest that $\beta$-glucosidase may be a minor component in the culture supernatant, and the production may be related to the production medium (Nazir et al., 2008). After purification, the enzyme showed a single band in SDS-PAGE, with the apparent molecular mass of about $120 \mathrm{kDa}$ (Fig. 1). Thus the enzyme was within the broad range of fungal $\beta$-glucosidase (35 to $250 \mathrm{kDa}$ ) (Song et al., 2011).

Table 1 Purification of $\beta$-glucosidase from $\boldsymbol{A}$. terreus

\begin{tabular}{lccccc}
\hline Purification step & Total protein $(\mathrm{mg})$ & Total activity (U) & Specific activity (U/mg) & Purification (fold) & Recovery (\%) \\
\hline Crude extract & $115.14 \pm 1.82$ & $258.83 \pm 4.12$ & $2.25 \pm 0.07$ & $1.00 \pm 0.02$ & $100.00 \pm 0.82$ \\
Ultra-filtraction & $58.06 \pm 1.11$ & $194.84 \pm 2.74$ & $3.36 \pm 0.53$ & $1.49 \pm 0.03$ & $75.28 \pm 0.75$ \\
HiTrap Q HP & $0.77 \pm 0.02$ & $19.72 \pm 0.88$ & $25.73 \pm 0.62$ & $11.45 \pm 0.53$ & $7.62 \pm 0.18$ \\
\hline Data represent the mean \pm SD $(n=3)$ & & & &
\end{tabular}




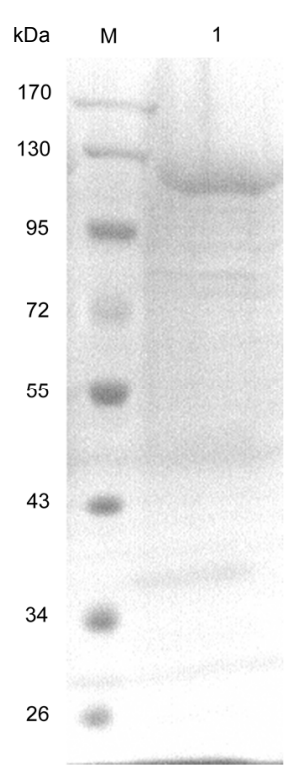

Fig. 1 SDS-PAGE of $A$. terreus $\beta$-glucosidase

$\mathrm{M}$, protein molecular weight marker (Thermo Fisher Scientific, Inc.); Lane 1, purified A. terreus $\beta$-glucosidase
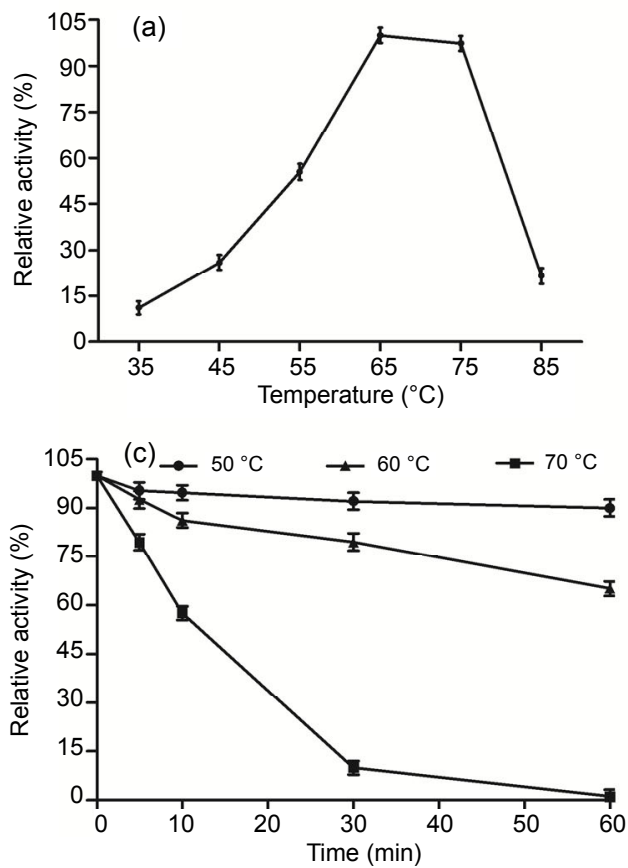

\subsection{Optimal pH and temperature, and stability}

The $\mathrm{pH}$ optima of most fungal $\beta$-glucosidases have a range between $\mathrm{pH} 4.0$ and 7.5 (Cairns and Esen, 2010). In this study, the purified $\beta$-glucosidase exhibited the highest activity at $\mathrm{pH} 5.0$ and was sensitive to $\mathrm{pH}$, while the activity decreased rapidly below $\mathrm{pH}$ 5.0 and above $\mathrm{pH} 7.0$ (Fig. 2b). Based on the relative activity of $100 \%$ for the $\beta$-glucosidase at $\mathrm{pH} 5.0$, only $23.6 \%$ and $64.5 \%$ of the maximum activity remained at $\mathrm{pH} 4.0$ and 6.0 , respectively. The optimal $\mathrm{pH}$ of the enzyme is similar to that of enzyme from A. terreus (Nazir et al., 2008), A. niger (Fujita et al., 2015), Penicillium piceum (Gao et al., 2013), and Rhizomисо miehei NRRL 5282 (Krisch et al., 2012). However, the enzyme was found to be very stable in the $\mathrm{pH}$ range from 3.0 to 8.0 , remaining above $90 \%$ of the maximum activity, though it showed a significant decrease with $\mathrm{pH}$ above or below $5.0(P<0.05$; Fig. 2d). Before reaching the distal part of the intestinal
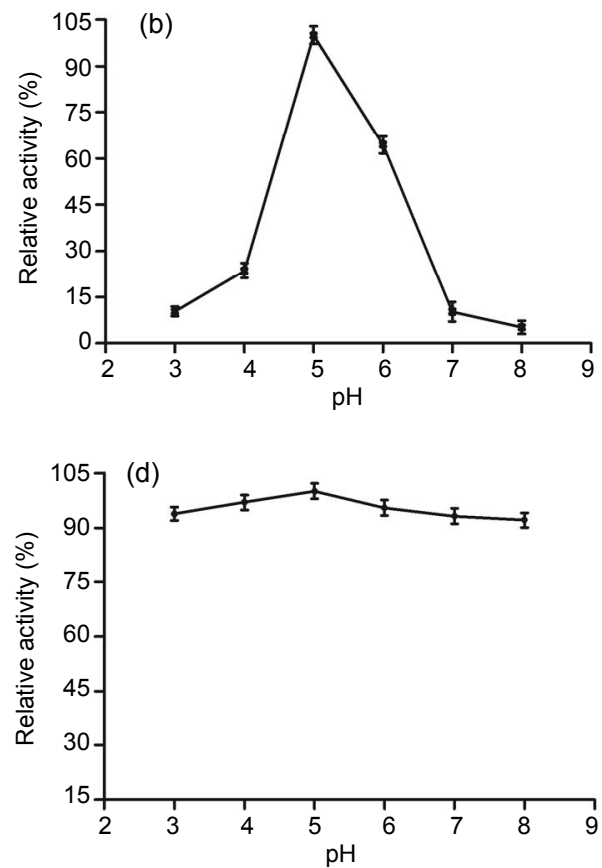

Fig. 2 Characterization of the purified $A$. terreus $\beta$-glucosidase

(a) Effect of temperature on A. terreus $\beta$-glucosidase activities. The activity was measured in McIlvaine buffer $(100 \mathrm{mmol} / \mathrm{L}, \mathrm{pH}$ 5.0) using $p$ NPG as the substrate. (b) Effect of $\mathrm{pH}$ on $A$. terreus $\beta$-glucosidase activities. The enzyme activities at various $\mathrm{pH}$ values were measured at $50{ }^{\circ} \mathrm{C}$ for $10 \mathrm{~min}$ using $p \mathrm{NPG}$ as the substrate. (c) Thermostability of $A$. terreus $\beta$-glucosidase. The residual activity was measured using $p \mathrm{NPG}$ as the substrate after pre-incubation without substrate at 50,60 , and $70^{\circ} \mathrm{C}$ for different periods of time. (d) $\mathrm{pH}$ stability of $A$. terreus $\beta$-glucosidase. The residual activities were measured at optimal conditions against $p$ NPG after incubation at various $\mathrm{pH}$ values, $25^{\circ} \mathrm{C}$ for $1 \mathrm{~h}$. The error bars represent the standard deviation (SD), with $n=3$ 
tract and exerting their catalytic effects, enzymes must retain activity during transport through the stomach and the upper part of the intestinal tract (Peng et al., 2014). The mean pH (fed ad libitum) values of the porcine stomach and small intestine are 4.4 and 6.1-6.7, respectively (Merchant et al., 2011). Therefore, the At-Bgl should have high potential for use as catalysts in animal feeds.

The purified $\beta$-glucosidase had an optimal temperature of $65^{\circ} \mathrm{C}$ (Fig. 2a), which was slightly higher than the previous reports (Li et al., 2012; 2013; Fujita et al., 2015; Kaur and Chadha, 2015; Zhao et al., 2015). In addition, the enzyme showed more than $97 \%$ relative activity at $75{ }^{\circ} \mathrm{C}$, and showed no significant difference from the activity at $65^{\circ} \mathrm{C}(P>0.05)$, while other fungal counterparts were generally inactivated at $70{ }^{\circ} \mathrm{C}$ (Li et al., 2013; Fujita et al., 2015; Kaur and Chadha, 2015; Zhao et al., 2015). Moreover, the At-Bgl showed good thermostability (Fig. 2c), maintaining $90.0 \%$ and $65.1 \%$ of the initial activity after incubation at 50 and $60{ }^{\circ} \mathrm{C}$ for $1 \mathrm{~h}$, respectively, though it decreased significantly after incubation at 50,60 , or $70{ }^{\circ} \mathrm{C}$ for $5 \mathrm{~min}(P<0.05)$. These superior properties make this purified enzyme more advantageous for industrial processes, since most applications of $\beta$-glucosidase require high temperatures (50 ${ }^{\circ} \mathrm{C}$ or above) (Li et al., 2012).

\subsection{Specific activity and kinetic parameters}

Kinetic parameters of the purified At-Bgl for $p$ NPG and cellobiose at $\mathrm{pH} 5.0$ and $65^{\circ} \mathrm{C}$ were estimated, respectively. The $K_{\mathrm{m}}$ and $V_{\max }$ values of the enzyme are shown in Table 2 . The results indicate that the enzyme has greater affinity towards $p$ NPG than cellobiose, and the hydrolysis of $p$ NPG was about eight times faster than that determined on cellobiose. It is worth mentioning that the $K_{\mathrm{m}}$ constant was slightly lower than those estimated for the At-Bgl in other reports, with a $K_{\mathrm{m}}$ value of $2.5 \mathrm{mmol} / \mathrm{L}$ (Elshafei et al., 2014) and 14.2, 4.34, $11.1 \mathrm{mmol} / \mathrm{L}$ (Nazir et al., 2008), respectively. To our best knowledge, there are reports about another two At-Bgls with lower $K_{\mathrm{m}}$ values of $0.78 \mathrm{mmol} / \mathrm{L}$ (Workman and Day, 1982) and $1.25 \mathrm{mmol} / \mathrm{L}$ (Rodionova et al., 1987), respectively. However, one of important drawbacks of those two enzymes is their low reaction temperatures, with optimal conditions of $50{ }^{\circ} \mathrm{C}$ (Workman and Day, 1982) and $60{ }^{\circ} \mathrm{C}$ (Rodionova et al., 1987), respectively.
Therefore, those At-Bgls are still not enough for satisfying biotechnological applications, and the purified At-Bgl in our study displayed high potential for industrial applications.

Table 2 Kinetic parameters of the purified $A$. terreus $\beta$-glucosidase

\begin{tabular}{lcc}
\hline \multicolumn{1}{c}{ Substrate } & $V_{\max }(\mathrm{U} / \mathrm{mg})$ & $K_{\mathrm{m}}(\mathrm{mmol} / \mathrm{L})$ \\
\hline Cellobiose & $5.70 \pm 0.17$ & $4.11 \pm 0.16$ \\
$p$ NPG & $42.37 \pm 0.74$ & $1.73 \pm 0.04$ \\
\hline
\end{tabular}

Data represent the mean $\pm \mathrm{SD}(n=3)$

\subsection{Tolerance to pepsin and trypsin}

The tolerance to the gastrointestinal microenvironment is important for the application of feed additives (Peng et al., 2014). As shown in Fig. 3, the purified $\beta$-glucosidase maintained high activity after the treatment with pepsin or trypsin, indicating its high tolerance towards the animal digestive tract. The enzyme maintained more than $90 \%$ of the initial activity after the incubation with pepsin (in both 1:1 and 1:0.2 ratios) for $120 \mathrm{~min}$. Moreover, the tolerance to trypsin is slightly lower than that to pepsin. The purified $\beta$-glucosidase retained $81.5 \%$ of the initial activity after incubating with trypsin (1:0.1) for $120 \mathrm{~min}$ and kept $87.4 \%$ of the initial activity when incubated with trypsin at a 1:0.02 ratio for $120 \mathrm{~min}$.

\subsection{Peptide sequence determination and protein identification}

The purified samples of $\beta$-glucosidase were denatured and analyzed by SDS-PAGE and subjected to MALDI-TOF/TOF MS analysis. The results indicated that the inner peptide sequence of purified protein in the present showed $100 \%$ identity with a $\beta$-glucosidase from $A$. terreus NIH2624 (GenBank Accession No. X_P001212225), which belonged to the GH3. The matched fragments were HYILNE QEHFR, DEYGFAHFFPSEGAYER, VNEFVNVQR, and VEDASSYLYPEGLKR.

\subsection{Hydrolysis of soybean isoflavone by $A$. terreus $\beta$-glucosidase}

Enzymatic hydrolysis of $\beta$-glucosidase towards soybean isoflavone is an important application in the food and feed industry, which has been investigated by direct use of $\beta$-glucosidase from plants and microorganisms (Chuankhayan et al., 2007; Kaya 

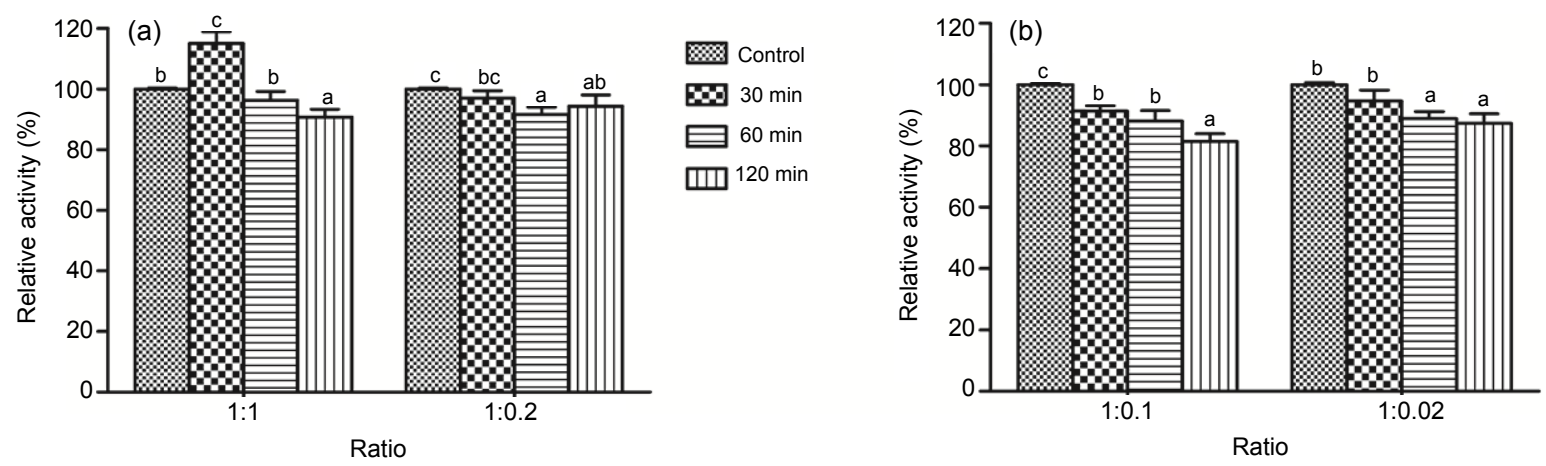

Fig. 3 Tolerance of $A$. terreus $\beta$-glucosidase to pepsin and trypsin

(a) The tolerance of $A$. terreus $\beta$-glucosidase to pepsin. The enzyme activity was measured at $65{ }^{\circ} \mathrm{C}, \mathrm{pH} 5.0$ (McIlvaine buffer, $100 \mathrm{mmol} / \mathrm{L})$ against $p \mathrm{NPG}$ after being pre-incubated in glycine- $\mathrm{HCl}$ buffer $(100 \mathrm{mmol} / \mathrm{L}, \mathrm{pH} 3.0)$ containing $0.1 \%$ pepsin for different intervals $(30,60$, and $120 \mathrm{~min})$. (b) The tolerance of $A$. terreus $\beta$-glucosidase to trypsin. The enzyme activity was measured at $65{ }^{\circ} \mathrm{C}$, pH 5.0 (Mcllvaine buffer, $100 \mathrm{mmol} / \mathrm{L}$ ) against $p$ NPG after being pre-incubated in Tris-HCl buffer $(100 \mathrm{mmol} / \mathrm{L}, \mathrm{pH} 7.0)$ containing $0.1 \%$ trypsin for different intervals. The error bars represent the SD $(n=3)$ and bars with different alphabets differ significantly $(P<0.05)$

et al., 2008; Yang et al., 2009; Song et al., 2011; Kim et al., 2012; Fang et al., 2014; Fujita et al., 2015). However, low solubility of isoflavones reduces the productivity of isoflavone aglycones in industrial production (Horii et al., 2009). To test the reactivity of At-Bgl toward isoflavone, the hydrolysis rate and the productivity were measured by HPLC using isoflavone flour extract as the substrate. The peaks of daidzin, genistin, glycitin, daidzein, genistein, and glycitein in soybean isoflavone flour extract were identified by comparison with commercial standards. The results showed that daidzin was the predominant isoflavones in soybean flour extract. However, after 10 min hydrolysis of At-Bgl, the peaks of daidzin, genistin, and glycitin were greatly decreased and the peaks of daidzein, genistein, and glycitein increased remarkably (Fig. 4b), which suggested that most of the glycosidic soybean isoflavones were converted to corresponding aglycones. As shown in Table 3, the At-Bgl exhibited higher hydrolytic activity than the commercial $\beta$-glucosidase cellobiase (Novozyme 188) toward daidzin, glycitin, and genistin $(95.78 \%$ vs. $59.16 \%, 72.08 \%$ vs. $23.07 \%$, and $86.74 \%$ vs. $54.15 \%$, respectively). Thus, the At-Bgl offers a better advantage for the hydrolysis of isoflavone $\beta$-glycoside (daidzin, glycitin, and genistin) than Novozyme 188.

The results indicate that At-Bgl also showed better productivity than Novozyme 188 after incubation for 10 min with $0.075 \mathrm{U}$ of At-Bgl. By comparison, the At-Bgl had the second highest productivity for daidzein $(1.14 \mathrm{mmol} /(\mathrm{L} \cdot \mathrm{h}))$ and genistein $(0.72 \mathrm{mmol} /(\mathrm{L} \cdot \mathrm{h}))$, much higher than that of
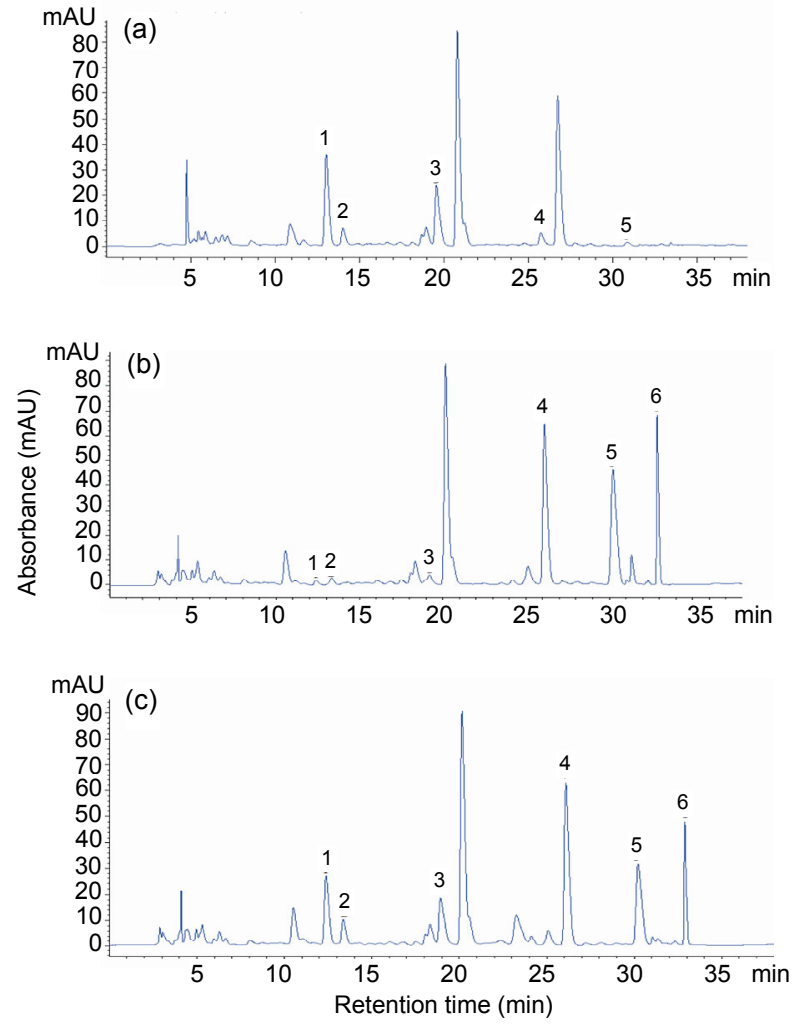

Fig. 4 HPLC chromatograms of isoflavones

(a) Isoflavones in soybean flour extract; (b) Soybean flour extract hydrolysed with $0.075 \mathrm{U}$ of $A$. terreus $\beta$-glucosidase at $50{ }^{\circ} \mathrm{C}$ for $10 \mathrm{~min}$; (c) Soybean flour extract hydrolysed with $0.075 \mathrm{U}$ of commercial $\beta$-glucosidase cellobiase Novozyme 188 at $50{ }^{\circ} \mathrm{C}$ for $10 \mathrm{~min}$. 1, daidzin; 2, glycitin; 3, genistin; 4 , daidzein; 5 , glycitein; 6 , genistein

$\beta$-glucosidase from A.oryzae (Horii et al., 2009), soybean okara (Chiou et al., 2010), and Pyrococcus furiosus (Yeom et al., 2012). In addition, the previously 
Table 3 Hydrolysis rates and productivities of $A$. terreus $\beta$-glucosidase and Novozyme 188 to soybean isoflavone

\begin{tabular}{|c|c|c|c|c|c|c|c|}
\hline \multirow{2}{*}{$\begin{array}{c}\text { Amount } \\
\text { (U) }\end{array}$} & \multirow{2}{*}{ Enzyme } & \multicolumn{3}{|c|}{ Hydrolysis rate $(\%)$} & \multicolumn{3}{|c|}{ Productivity $(\mathrm{mmol} /(\mathrm{L} \cdot \mathrm{h}))$} \\
\hline & & Daidzin & Glycitin & Genistin & Daidzein & Glycitein & Genistein \\
\hline \multirow[t]{2}{*}{0.025} & At-Bgl & $32.76 \pm 0.28^{\mathrm{A}}$ & $27.58 \pm 0.10^{\mathrm{B}}$ & $28.78 \pm 0.13^{\mathrm{B}}$ & $0.41 \pm 0.02^{\mathrm{a}}$ & $0.08 \pm 0.01^{\mathrm{c}}$ & $0.24 \pm 0.02^{\mathrm{b}}$ \\
\hline & Nov 188 & $10.31 \pm 0.03^{\mathrm{C}}$ & $12.38 \pm 0.02^{\mathrm{A}}$ & $11.97 \pm 0.03^{\mathrm{B}}$ & $0.15 \pm 0.02^{\mathrm{a}}$ & $0.03 \pm 0.01^{\mathrm{c}}$ & $0.08 \pm 0.01^{\mathrm{b}}$ \\
\hline \multirow[t]{2}{*}{0.050} & At-Bgl & $95.46 \pm 0.22^{\mathrm{A}}$ & $64.25 \pm 0.29^{\mathrm{C}}$ & $84.68 \pm 0.38^{\mathrm{B}}$ & $1.06 \pm 0.06^{\mathrm{a}}$ & $0.18 \pm 0.03^{\mathrm{c}}$ & $0.68 \pm 0.02^{\mathrm{b}}$ \\
\hline & Nov 188 & $34.04 \pm 0.04^{\mathrm{A}}$ & $20.58 \pm 0.28^{\mathrm{C}}$ & $28.52 \pm 0.29^{\mathrm{B}}$ & $0.57 \pm 0.02^{\mathrm{a}}$ & $0.07 \pm 0.01^{\mathrm{c}}$ & $0.19 \pm 0.02^{\mathrm{b}}$ \\
\hline \multirow[t]{2}{*}{0.075} & At-Bgl & $95.78 \pm 0.20^{\mathrm{A}}$ & $72.08 \pm 0.08^{\mathrm{C}}$ & $86.74 \pm 0.04^{\mathrm{B}}$ & $1.14 \pm 0.01^{\mathrm{a}}$ & $0.19 \pm 0.01^{\mathrm{c}}$ & $0.72 \pm 0.03^{\mathrm{b}}$ \\
\hline & Nov 188 & $59.16 \pm 0.16^{\mathrm{A}}$ & $23.07 \pm 0.04^{\mathrm{C}}$ & $54.15 \pm 0.16^{\mathrm{B}}$ & $0.84 \pm 0.04^{\mathrm{b}}$ & $0.13 \pm 0.02^{\mathrm{a}}$ & $0.40 \pm 0.02^{c}$ \\
\hline
\end{tabular}

The reactions were performed in Mcllvaine buffer $(100 \mathrm{mmol} / \mathrm{L}, \mathrm{pH} 5.0)$ containing $50 \mu$ l soybean isoflavone flour extract and 0.025 , 0.050 , or $0.075 \mathrm{U} \beta$-glucosidase. All reactions were performed at $50^{\circ} \mathrm{C}$ for $10 \mathrm{~min}$. At-Bgl: $\beta$-glucosidase from Aspergillus terreus. Nov 188: commercial $\beta$-glucosidase cellobiase Novozyme 188. Data (mean $\pm \operatorname{SD}(n=3))$ with different superscripts within a row differ significantly $(P<0.05)$

reported highest productivities for daidzein and genistein were 1.50 and $1.23 \mathrm{mmol} /(\mathrm{L} \cdot \mathrm{h})$, respectively, produced by a $\beta$-glucosidase from Gongronella sp. (Fang et al., 2014). To the best of our knowledge, this is the first report of an At-Bgl hydrolyzing soybean isoflavones and its high hydrolysis rates of daidzin and genistin, and the second highest productivity for daidzein and genistein makes it a good candidate for hydrolysis of soybean isoflavones.

\section{Conclusions}

The purified $\beta$-glucosidase from $A$. terreus, a member of GH3, is a promising enzyme to be used as feed additives. The purified enzyme exhibited maximal activity at $\mathrm{pH} 5.0$ and $65^{\circ} \mathrm{C}$. Moreover, the enzyme had multiple industrial desired properties, including thermostability, wide $\mathrm{pH}$ stability, and high tolerance to pepsin and trypsin. And its high efficiency to convert soybean isoflavone glycosides into aglycones was very attractive. Thus, At-Bgl might perform substantially to enhance nutritional value of soy products, such as soybean meal which is widely used in animal feeds. The study indicated that At-Bgl offers high potential for commercialization and is valuable in various industrial applications, especially in food and feeds.

\section{Compliance with ethics guidelines}

Feng-ying YAN, Wei XIA, Xiao-xu ZHANG, Sha CHEN, Xin-zheng NIE, and Li-chun QIAN declare that they have no conflict of interest.

This article does not contain any studies with human or animal subjects performed by any of the authors.

\section{References}

Alekel, D.L., Genschel, U., Koehler, K.J., et al., 2015. Soy Isoflavones for Reducing Bone Loss Study: effects of a 3-year trial on hormones, adverse events, and endometrial thickness in postmenopausal women. Menopause, 22(2): 185-197. http://dx.doi.org/10.1097/GME.0000000000000280

Cairns, J.R.K., Esen, A., 2010. $\beta$-Glucosidases. Cell. Mol. Life Sci., 67(20):3389-3405. http://dx.doi.org/10.1007/s00018-010-0399-2

Chiou, T.Y., Lin, Y.H., Su, N.W., et al., 2010. $\beta$-Glucosidase isolated from soybean okara shows specificity toward glucosyl isoflavones. J. Agric. Food Chem., 58(15): 8872-8878.

http://dx.doi.org/10.1021/jf101848x

Chuankhayan, P., Rimlumduan, T., Svasti, J., et al., 2007. Hydrolysis of soybean isoflavonoid glycosides by $\mathrm{Dal}$ bergia $\beta$-glucosidases. J. Agric. Food Chem., 55(6): 2407-2412. http://dx.doi.org/10.1021/jf062885p

Coughlan, M.P., 1985. The properties of fungal and bacterial cellulases with comment on their production and application. Biotechnol. Genet. Eng. Rev., 3(1):39-110. http://dx.doi.org/10.1080/02648725.1985.10647809

de Cassia Pereira, J., Leite, R.S.R., do Prado, H.F.A., et al., 2015. Production and characterization of $\beta$-glucosidase obtained by the solid-state cultivation of the thermophilic fungus Thermomucor indicae-seudaticae N31. Appl. Biochem. Biotechnol., 175(2):723-732. http://dx.doi.org/10.1007/s12010-014-1332-1

Elshafei, A.M., Hassan, M.M., Morsi, N.M., et al., 2014. Purification and some kinetic properties of $\beta$-glucosidase from Aspergillus terreus NRRL 265. Afr. J. Biotechnol., 10(84): 19556-19569.

Fang, W., Song, R., Zhang, X., et al., 2014. Characterization of a novel $\beta$-glucosidase from Gongronella sp. W5 and its application in the hydrolysis of soybean isoflavone glycosides. J. Agric. Food Chem., 62(48):11688-11695. http://dx.doi.org/10.1021/jf502850z

Fujita, A., Alencar, S.M., Park, Y.K., 2015. Conversion of 
isoflavone glucosides to aglycones by partially purified $\beta$-glucosidases from microbial and vegetable sources. Appl. Biochem. Biotechnol., 176(6):1659-1672. http://dx.doi.org/10.1007/s12010-015-1668-1

Gao, L., Gao, F., Zhang, D., et al., 2013. Purification and characterization of a new $\beta$-glucosidase from Penicillium piceum and its application in enzymatic degradation of delignified corn stover. Bioresour. Technol., 147:658-661. http://dx.doi.org/10.1016/j.biortech.2013.08.089

Gueguen, Y., Chemardin, P., Janbon, G., et al., 1996. A very efficient $\beta$-glucosidase catalyst for the hydrolysis of flavor precursors of wines and fruit juices. J. Agric. Food Chem., 44(8):2336-2340. http://dx.doi.org/10.1021/jf950360j

Horii, K., Adachi, T., Matsuda, T., et al., 2009. Improvement of isoflavone aglycones production using $\beta$-glucosidase secretory produced in recombinant Aspergillus oryzae. $J$. Mol. Catal. B Enzym., 59(4):297-301. http://dx.doi.org/10.1016/j.molcatb.2008.11.013

Imai, S., 2015. Soybean and processed soy foods ingredients, and their role in cardiometabolic risk prevention. Recent Pat. Food Nutr. Agric., 7(2):75-82. http://dx.doi.org/10.2174/2212798407666150629123839

Izumi, T., Piskula, M.K., Osawa, S., et al., 2000. Soy isoflavone aglycones are absorbed faster and in higher amounts than their glucosides in humans. J. Nutr., 130(7):1695-1699.

Kaur, A., Chadha, B.S., 2015. Penicillium janthinellum: a source of efficient and high levels of $\beta$-glucosidase. Appl. Biochem. Biotechnol., 175(2):937-949. http://dx.doi.org/10.1007/s12010-014-1330-3

Kaya, M., Ito, J., Kotaka, A., et al., 2008. Isoflavone aglycones production from isoflavone glycosides by display of $\beta$-glucosidase from Aspergillus oryzae on yeast cell surface. Appl. Microbiol. Biotechnol., 79(1):51-60. http://dx.doi.org/10.1007/s00253-008-1393-6

Kim, B.N., Yeom, S.J., Kim, Y.S., et al., 2012. Characterization of a $\beta$-glucosidase from Sulfolobus solfataricus for isoflavone glycosides. Biotechnol. Lett., 34(1):125-129. http://dx.doi.org/10.1007/s10529-011-0739-9

Ko, K.P., 2013. Isoflavones: chemistry, analysis, functions and effects on health and cancer. Asian Pac. J. Cancer Prev., 15(17):7001-7010. http://dx.doi.org/10.7314/APJCP.2014.15.17.7001

Krisch, J., Bencsik, O., Papp, T., et al., 2012. Characterization of a $\beta$-glucosidase with transgalactosylation capacity from the zygomycete Rhizomucor miehei. Bioresour. Technol., 114:555-560. http://dx.doi.org/10.1016/j.biortech.2012.02.117

Kudou, S., Fleury, Y., Welti, D., et al., 1991. Malonyl isoflavone glycosides in soybean seeds (Glycine max Merrill). Agric. Biol. Chem., 55(9):2227-2233. http://dx.doi.org/10.1080/00021369.1991.10870966

Laemmli, U.K., 1970. Cleavage of structural proteins during the assembly of the head of bacteriophage T4. Nature, 227(5259):680-685. http://dx.doi.org/10.1038/227680a0
Li, G., Jiang, Y., Fan, X.J., et al., 2012. Molecular cloning and characterization of a novel $\beta$-glucosidase with high hydrolyzing ability for soybean isoflavone glycosides and glucose-tolerance from soil metagenomic library. Bioresour. Technol., 123:15-22. http://dx.doi.org/10.1016/j.biortech.2012.07.083

Li, X., Zhao, J., Shi, P., et al., 2013. Molecular cloning and expression of a novel $\beta$-glucosidase gene from Phialophora sp. G5. Appl. Biochem. Biotechnol., 169(3):941-949. http://dx.doi.org/10.1007/s12010-012-0048-3

Matsuura, M., Obata, A., 1993. $\beta$-Glucosidases from soybeans hydrolyze daidzin and genistin. J. Food Sci., 58(1):144-147. http://dx.doi.org/10.1111/j.1365-2621.1993.tb03231.x

Merchant, H.A., McConnell, E.L., Liu, F., et al., 2011. Assessment of gastrointestinal $\mathrm{pH}$, fluid and lymphoid tissue in the guinea pig, rabbit and pig, and implications for their use in drug development. Eur. J. Pharm. Sci., 42(1-2):3-10. http://dx.doi.org/10.1016/j.ejps.2010.09.019

Nazir, A., Soni, R., Saini, H., et al., 2008. Regulation of expression of multiple $\beta$-glucosidases of Aspergillus terreus and their purification and characterization. Bioresources, 4(1):155-171.

Oda, K., Kakizono, D., Yamada, O., et al., 2006. Proteomic analysis of extracellular proteins from Aspergillus oryzae grown under submerged and solid-state culture conditions. Appl. Environ. Microbiol., 72(5):3448-3457. http://dx.doi.org/10.1128/AEM.72.5.3448-3457.2006

Peng, Z., Wang, A., Feng, Q., et al., 2014. High-level expression, purification and characterisation of porcine $\beta$ defensin 2 in Pichia pastoris and its potential as a costefficient growth promoter in porcine feed. Appl. Microbiol. Biotechnol., 98(12):5487-5497.

http://dx.doi.org/10.1007/s00253-014-5560-7

Ravindranath, M.H., Muthugounder, S., Presser, N., et al., 2004. Anticancer therapeutic potential of soy isoflavone, genistein. In: Cooper, E.L., Yamaguchi, N. (Eds.), Complementary and Alternative Approaches to Biomedicine. Springer US, p.121-165.

http://dx.doi.org/10.1007/978-1-4757-4820-8_11

Rodionova, N.A., Tavobilov, I.M., Martinovich, L.I., et al., 1987. $\beta$-Glucosidases from cellulolytic fungi Aspergillus terreus, Geotrichum candidum, and Trichoderma longibrachiatum as typical glycosidases. Biotechnol. Appl. Biochem., 9(3):239-250. http://dx.doi.org/10.1111/j.1470-8744.1987.tb00475.x

Song, X., Xue, Y., Wang, Q., et al., 2011. Comparison of three thermostable $\beta$-glucosidases for application in the hydrolysis of soybean isoflavone glycosides. J. Agric. Food Chem., 59(5):1954-1961.

http://dx.doi.org/10.1021/jf1046915

Souza, F.H.M., Nascimento, C.V., Rosa, J.C., et al., 2010. Purification and biochemical characterization of a mycelial glucose-and xylose-stimulated $\beta$-glucosidase from the thermophilic fungus Humicola insolens. Process Biochem., 45(2):272-278. http://dx.doi.org/10.1016/j.procbio.2009.09.018 
Ullah, M.F., Bhat, S.H., Husain, E., et al., 2016. Pharmacological intervention through dietary nutraceuticals in gastrointestinal neoplasia. Crit. Rev. Food Sci. Nutr., 56(9): 1501-1518 http://dx.doi.org/10.1080/10408398.2013.772091

Workman, W.E., Day, D.F., 1982. Purification and properties of $\beta$-glucosidase from Aspergillus terreus. Appl. Microbiol. Biotechnol., 44(6):1289-1295.

Yang, S., Wang, L., Yan, Q., et al., 2009. Hydrolysis of soybean isoflavone glycosides by a thermostable $\beta$-glucosidase from Paecilomyces thermophila. Food Chem., 115(4): 1247-1252. http://dx.doi.org/10.1016/j.foodchem.2009.01.038

Yeom, S.J., Kim, B.N., Kim, Y.S., et al., 2012. Hydrolysis of isoflavone glycosides by a thermostable $\beta$-glucosidase from Pyrococcus furiosus. J. Agric. Food Chem., 60(6): 1535-1541. http://dx.doi.org/10.1021/jf204432g

Zhao, J., Guo, C., Tian, C., et al., 2015. Heterologous expression and characterization of a GH3 $\beta$-glucosidase from thermophilic fungi Myceliophthora thermophila in Pichia pastoris. Appl. Biochem. Biotechnol., 177(2):511-527. http://dx.doi.org/10.1007/s12010-015-1759-z

Zhou, C., Qian, L., Ma, H., Yu, X., et al., 2012. Enhancement of amygdalin activated with $\beta$-D-glucosidase on HepG2 cells proliferation and apoptosis. Carbohydr. Polym., 90(1):516-523.

http://dx.doi.org/10.1016/j.carbpol.2012.05.073

\section{List of electronic supplementary materials}

Fig. S1 Morphology of $A$. terrues culture mycelium

\section{中文概要}

题 目: 土曲霉来源的 $\beta$-葡萄糖苷酶的酶学特性及其对 大豆异黄酮的水解

目 的: 分离纯化土曲霉来源的 $\beta$-葡萄糖苷酶 (At-Bgl), 探究其酶学特性及其对大豆异黄酮的水解效果。

创新点: 成功将 At-Bgl 分离纯化出来, 并首次将分离纯化 后的 At-Bgl 应用于水解大豆异黄酮糖苷。

方 法: 利用超滤、透析、阴离子交换柱层析和聚丙烯酰 氨凝胶电泳 (SDS-PAGE) 等手段分离纯化土曲 霉来源的 $\beta$-葡萄糖苷酶（表 1)，并用解析电离 串联飞行时间质谱技术 (MALDI-TOF/TOF MS) 鉴定蛋白条带。以对硝基苯基 $\beta$ - $\mathrm{D}$ - 葡萄糖苷 $(p N P G)$ 为底物进行酶学特性研究; 以 $p N P G$ 和纤维二糖为底物, 进行酶动力学参数研究 （表 2); 以胃蛋白酶和胰蛋白酶模拟动物胃肠 道酸性环境, 进行酸耐受性研究。通过高效液相 色谱（HPLC）检测 At-Bgl 对大豆异黄酮糖苷的 水解效果（表 3)。

结 论: At-Bgl 属糖苷水解酶第三家族 ( GH3), 分子量 约为 $120 \mathrm{kDa}$ (图 1), 最适酶解条件为 $\mathrm{pH} 5.0$ 和 $65^{\circ} \mathrm{C}$, 具有良好的热稳定性和 $\mathrm{pH}$ 稳定性(图 2), 且胃蛋白酶和胰蛋白酶耐受性强 (图 3)。At-Bgl 可将大豆异黄酮糖苷高效转化为异黄酮苷元 （图 4)。综上所述, At-Bgl 在增强动物胃肠道 对大豆异黄酮的水解方面具有重要应用价值。

关键词： $\beta$-葡萄糖苷酶; 土曲霉; 酶学特性; 水解; 大豆 异黄酮 